\title{
PERIODIC INSPECTION OF SPRAYERS: DIAGNOSTIC TO THE NORTHERN OF PARANÁ
}

\section{MARCO A. GANDOLFO ${ }^{1}$, ULISSES R. ANTUNIASSI ${ }^{2}$, ULISSES D. GANDOLFO ${ }^{3}$, EDER D. DE MORAES ${ }^{4}$, EURÍPEDES B. RODRIGUES ${ }^{5}$, FERNANDO S. ADEGAS $^{6}$}

\begin{abstract}
To optimize the use of pesticides, several countries have carried out periodic inspections in agricultural sprayers. In Brazil, knowing the conditions of this machinery can guide researches and investments in guidelines for its use and maintenance. The objective of this study was to verify the state of sprayer maintenance used in the North of the state of Paraná, in Brazil. Several sprayer items were evaluated, such as: presence, status and scale of the manometer, status of the hose, status of the anti-drip component, presence of leaks, status of the bar, status of the filters, state of the spraying nozzles and errors in the targeted flow rate. Machines were named as approved when there was no failure in any item evaluated. The factor that caused the biggest level of reprove among the machines was incorrect scale of manometers, which reproved $84.55 \%$ of the machines evaluated. Other outstanding factor was the incorrect flow rate in $75.5 \%$ of the tested machines. Only one unit was approved from the total of 110 evaluated sprayers.
\end{abstract}

KEYWORDS: periodic inspection, sprayer, quality of application.

\section{INSPEÇÃO PERIÓDICA DE PULVERIZADORES: DIAGNÓSTICO PARA A REGIÃO NORTE DO PARANÁ}

RESUMO: Para a otimização no uso de agroquímicos, vários países têm realizado inspeções periódicas em pulverizadores agrícolas. No Brasil, o conhecimento do estado destas máquinas pode nortear pesquisas e investimentos em orientação de uso e de manutenção das mesmas. O objetivo deste trabalho foi verificar o estado de manutenção de pulverizadores em uso para a região norte do Estado do Paraná. Foram avaliados itens como: presença, estado e escala do manômetro, estado das mangueiras, estado dos antigotejadores, presença de vazamentos, estado da barra, estado dos filtros, estado das pontas de pulverização e erros na taxa de aplicação. As máquinas foram caracterizadas como aprovadas quando não havia falha em nenhum item avaliado. $\mathrm{O}$ fator que ocasionou o maior índice de reprova entre as máquinas foi a escala incorreta do manômetro, que reprovou 84,55\% das máquinas avaliadas. Outro fator de destaque foi a taxa de aplicação incorreta em $75,5 \%$ das máquinas. Do total dos 110 pulverizadores avaliados, apenas uma unidade foi aprovada.

PALAVRAS-CHAVE: inspeção periódica, pulverizador, qualidade de aplicação.

\footnotetext{
${ }^{1}$ Eng $^{\mathrm{o}}$ Agrônomo, Prof. Adjunto, Depto. de Engenharia e Desenvolvimento Agrário. UENP. Campus Luiz Meneghel, Bandeirantes PR.

${ }^{2}$ Eng ${ }^{0}$ Agrônomo, Prof. Titular, Depto. de Engenharia Rural, Faculdade de Ciências Agronômicas - UNESP, Câmpus de Botucatu.

${ }^{3}$ Eng ${ }^{\circ}$ Agrônomo, Graduação Universidade Estadual do Norte do Paraná, Pós-Graduação a nível de Mestrado em Tecnologia de Aplicação, Programa Energia na Agricultura, UNESP/FCA, Botucatu, ulissesgandolfo@ fca.unesp.br.

${ }^{4}$ Acadêmico do Curso de Agronomia, Universidade Estadual Norte do Paraná, UENP, Bandeirantes - PR.

${ }^{5}$ Prof. M.Sc., Universidade Estadual do Norte do Paraná, Departamento de Engenharia e Desenvolvimento Agrário.

${ }^{6}$ Dr., Pesquisador, Embrapa Soja, Londrina - PR.

Recebido pelo Conselho Editorial em: 5-12-2011
}

Aprovado pelo Conselho Editorial em: 15-10-2012 


\section{INTRODUCTION}

The increasing demand for food production, along with economic needs of the productive sector of agriculture, has led the search and the use of new techniques that enable higher productivity areas already explored. The use of agrochemicals occupies a prominent place among the techniques used to improve both yield and quality of products from productive agricultural areas, particularly in combating diseases, weeds and pests of cultivated plants.

CUNHA \& RUAS (2006) reported that most of the time during the chemical control of pests, diseases and weeds, there is a lot of importance to the agrochemical and little focus on application technique. The consequence is loss of effectiveness, if not the total failure of treatment with overdosing or underdosing, leading to loss of production and damage to the environment and human health itself. However, to SILVEIRA et al. (2006), this scenario can only change if the agrochemical application equipment are reviewed and calibrated periodically.

The efficiency of application of agrochemicals against agents that cause damage to crops, associated with a lower environmental contamination and lower cost, depends on several factors. Among them is the correct calibration of equipment. This can be achieved by mandating the review of application equipment and training of its operators, as is already done in some European countries (GANZELMEIER \& WEHMANN, 2007).

For SANTOS \& MACIEL (2006), lack of knowledge about favorable conditions to the implementation, mainly the lack of temperature and wind speed, contributes greatly to the loss of application quality. Thus, it is also important to know how operators evaluate these conditions to define by the beginning or not of the application.

Studies of inspection of sprayers in Brazil have been conducted by several researchers, among them GANDOLFO \& ANTUNIASSI (2003), ANTUNIASSI \& GANDOLFO (2005), BAUER et al. (2006) and GANDOLFO et al. (2007). Generally, results showed high level of errors in various parameters.

Considering that the agrochemicals market in Brazil increased from six hundred million dollars in 1994 to over two billion and one hundred million dollars in 1997, topping six billion dollars in 2008 (Thematic Chamber of Agricultural and Livestock Inputs - CTIA, 2009), and that these applications, when excessive, can consume up to $400 \%$ more than the required amount of product, enables evaluating the importance of having a control over the status of machines that applies most of these products, from both the economically and environmentally point of views.

SILVEIRA et al. (2006), through inspections carried out in the region of Cascavel, in the state of Paraná - PR, Brazil, found that $34.0 \%$ of the nozzles used in applications of agrochemicals were worn, which provided an application rate above the tolerable limit, which was set at about $5 \%$ in relation to the intended by the user.

Thus, the identification of the current state of conservation and use of agricultural sprayers can guide further researches and investments for maintenance and proper use, in order to contribute to reducing costs and environmental contamination by lower consumption and lower losses associated with greater efficiency spraying.

The objective of this study was to evaluate the condition of use, from the maintenance and calibration status of agricultural sprayers in the Northern Region of the State of Paraná.

\section{MATERIAL AND METHODS}

The study was coordinated by the Center for Research in Pesticide Application and Agricultural Machinery Technology - NITEC State University of Northern Paraná - Luiz Meneghel Campus - Bandeirantes - PR, along with the Cocamar Agroindustrial Cooperative of Maringá - PR.

The assessed equipment items, as well as provision parameters and their approval limits considered in the inspections conducted in this study were proposed by GANDOLFO \& 
ANTUNIASSI (2003). Evaluations were conducted in the Northern Paraná Region, from May 2008 to November 2009, and inspections occurred in properties where the machines were being used.

The number of machines inspected, according to location, is shown in Table 1.

TABLE 1. Location and number of evaluated machines.

\begin{tabular}{cc|cc}
\hline Location & Number of Machines & Location & Number of Machines \\
\hline Atalaia & 14 & Ivatuba & 2 \\
Cianorte & 11 & Jussara & 9 \\
Dr. Camargo & 5 & Mandaguarí & 1 \\
Floraí & 6 & Maringá & 12 \\
Floresta & 10 & Ourizona & 4 \\
Francisco Alves & 1 & São Jorge do Ivaí & 13 \\
Iporã & 3 & & \\
\hline
\end{tabular}

Items considered for equipment evaluation, as well as the limits of errors between the values obtained on the machine in use and the reference values, were established as proposed by GANDOLFO \& ANTUNIASSI (2003) and are described below:

\section{Manometer presence, functionality and adjustment}

This review was firstly made by assessing the presence or absence of the manometer. With the machine running it was possible to observe if the manometer dial, when present, was indicating different pressure values between the machines when switched off and when running. Other verification performed, based on proposals of HUYGHEBAERT et al. (1996) and LANGENAKENS (1999) was the adjustment of manometers, where depending on the maximum scale of them, they were characterized as appropriate or not. The machine condition with adequate manometer was assigned to those with work pressure between $25 \%$ and $75 \%$ of full scale of the machine manometer at the time of inspection. This review was performed based on the NBR$12446 / 1992$ standard, which establishes that evaluations of fault tolerance of gauges must be between 25 and $75 \%$ of full scale.

\section{Status and positioning of hoses}

Broken, cracked and fissured hoses or with other kinds of damages have been identified and located. There was also the position of the hoses, identifying and locating the projection that interfered with the jet of liquid from the nozzle to the target, considering them as poorly located. This review was based on proposals of HUYGHEBAERT et al. (1996) and LANGENAKENS (1999).

\section{Presence and status of anti-drip mechanisms}

Besides the presence, they were considered as functional when, after the interruption of the spraying, the passage of liquid through the tip stopped completely and instantly. When, after ceasing pumping water to the bars, the ends kept dripping, anti-drip mechanisms were considered nonfunctional.

\section{Presence of Leakage}

The presence of leakage was assessed by starting the machine and observing whether it had any leaks, regardless of the amount lost. Drips in different locations of the anti-drip mechanisms were considered in this item, identified in the worksheet where occurred.

\section{Presence and status of line filters}

The filter, if present, was removed after dynamic assessments, and observation was performed considering the presence of cracks, clogging or other damages, both in the mesh, as in the housing, similar to that performed by HUYGHERBAERT et al. (1996). 


\section{Presence and status of suction filters}

The procedure for this study was similar to that conducted for line filters, also following the proposed by HUYGHERBAERT et al. (1996).

\section{Status of spraying nozzles}

The status of these components was assessed through their flow. Flexible hoses were installed in nozzle bodies, which were designed to lead all of the water sprayed into the interior of the buckets positioned under each of the nozzles.

The machine was put into operation and, after 30 seconds operating, in order to stabilize the pressure in the hydraulic circuit, two stopwatches started a count. Along with the start of time count of the stopwatches, the first bucket was placed under the tube of the first nozzle. Holding one of the stopwatches, a person placed a bucket under each of the hoses every five seconds until the last nozzle. A minute after placing the first bucket, another person holding another stopwatch withdrew the first bucket and every five seconds he withdrew the others until the last nozzle. Thus, each bucket was collecting the sprayed liquid during 60 seconds.

The volume of liquid collected in each bucket was estimated by weighing on an electronic scale. Nozzles were considered bad when the difference of the percentage of each nozzle flow exceeded $10 \%$ of the average flow of all of them. To determine the average flow of the nozzles, flow values with a difference greater than $10 \%$ lower than average, since it did not correspond to obstructed nozzle flow, thus not characterizing wear, were excluded from the calculation. Still, these nozzles were included in the statistical analysis as inadequate for having incorrect flow.

\section{Application rate errors}

The calibration using the accuracy method is obtained by the total mass of the sprayed liquid by the nozzles obtained on weighing $(\mathbf{Q t})$. The displacement speed of the tractor-implement set was also considered. This speed was determined from measuring the time taken for the set to run a distance of 100m; this time was measured in seconds and was identified as (t1).

Displacement speed $(\mathbf{V})$ was calculated as follows:

$$
\mathrm{V}=6000 \mathrm{t} 1^{-1}
$$

where,

$\mathrm{V}$ - speed, $\mathrm{m} \mathrm{mim}^{-1}$, and

$\mathrm{t} 1$ - time for the set to run a distance of 100 meters.

The distance between the bar end nozzles (d) and average space effectively used between the nozzles (Em) were measured in meters. The sprayer effective width was determined as follows:

$$
\mathrm{L}=\mathrm{d}+\mathrm{Em}
$$

where,

L - working width, m;

$\mathrm{d}$ - distance between nozzles of both bar ends, $\mathrm{m}$, and

Em - average space between nozzles, $\mathrm{m}$.

The real set application rate (Ta) was obtained by the following equation:

$$
\mathrm{Ta}=\mathrm{Qt}\left(\{\mathrm{L} \mathrm{V}\} 10000^{-1}\right)^{-1}
$$

where,

Ta - application rate, $\mathrm{L} \mathrm{ha}^{-1}$;

$\mathrm{Qt}$ - end sprayed liquid mass sum, $\mathrm{L} \mathrm{min}^{-1}$;

L - working width, $\mathrm{m}$, and

$\mathrm{V}$ - displacement speed, $\mathrm{m} \mathrm{mim}^{-1}$. 
The percentage of error in application rates between those determined by users and those obtained by the precision method proposed in this study was determined by comparing both of them. The application rate effectively applied by machine was considered wrong when the percentage difference exceeded the threshold of $5 \%$ more or less in relation to the intended by the equipment user.

\section{RESULTS AND DISCUSSION}

\section{Manometer assessment}

From the 91 machines assessed, 77 units (84.6\%) were considered as missing, inadequate or non-functional for use in sprayers. The missing or damaged ones were only four units $(4.4 \%)$ and 75 machines $(82.4 \%)$ were inadequate. SILVEIRA (2006) evaluated sprayers in the region of Cascavel - PR, and found that $48.0 \%$ of the assessed machines did not have a manometer. Results obtained by GANDOLFO \& ANTUNIASSI (2003) showed that $93.4 \%$ of the evaluated machines in the states of Parana and São Paulo also presented problems with the manometers. LANGENAKENS (1999) found the same problem in $20 \%$ of sprayers in tests conducted in Belgium.

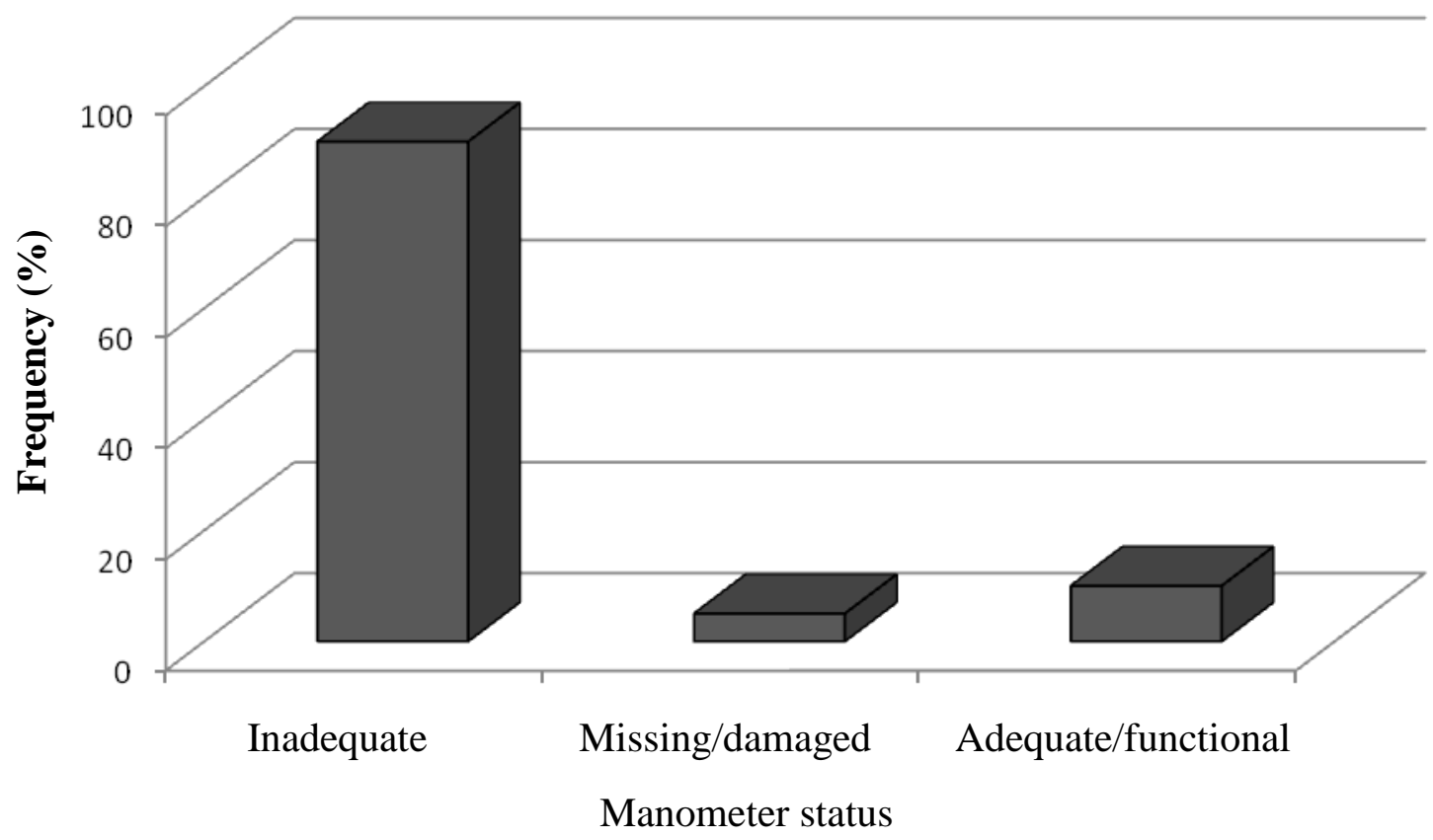

FIGURE 1. Evaluation of manometer use condition. Status and position of hoses.

The analysis revealed that 42 machines (46.2\%) were being used with problems related to the condition of hoses and that the average of poor hoses per machine, considering only those with a poor hose, was of 3.6 units. As for misplaced hoses, it occurred in 29 units (31.9\%) and the average occurrence of this problem by machine was 2.2 units. The poor location of the hoses was observed in only $0.8 \%$ of machines in Belgium (LANGENAKENS, 1999). When considering the occurrence of either problems, poor hose or poorly located hose, 52 units $(57.1 \%)$ were considered with at least one inadequate condition. This value was similar to that observed by GANDOLFO \& ANTUNIASSI (2003), who found this problem in $48.7 \%$ of the inspected machines. 


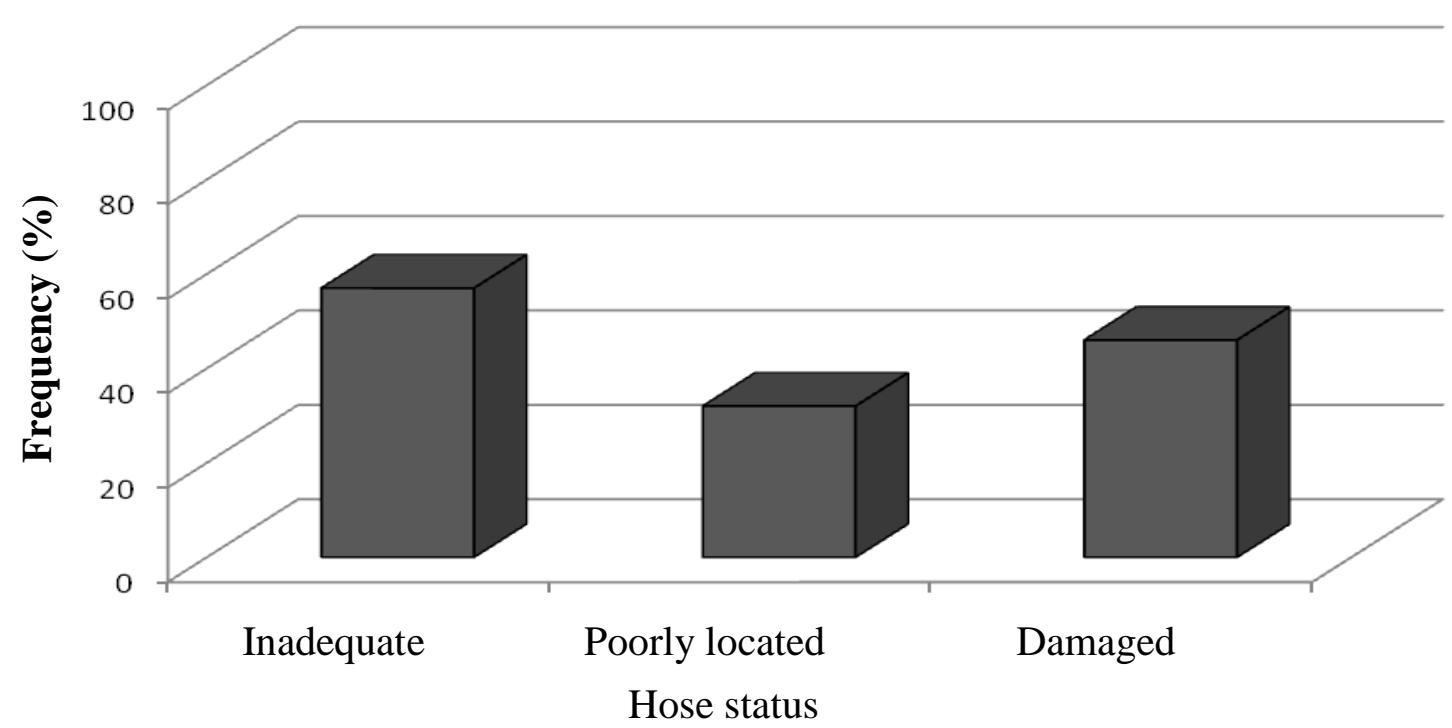

FIGURE 2. Evaluation of hoses use condition.

\section{Presence and status of anti-drip mechanisms}

Since anti-drip mechanisms are not considered as mandatory items in sprayers, they were present in 81 units $(89.0 \%)$, while the others did not have this device. Ten units $(11.0 \%)$ had at least one nonfunctional anti-drip mechanism from those machines that presented it. The average number of problems with anti-drip mechanisms by machine was 2.7 units with a machine with 14 nonfunctional anti-drip mechanisms. Surveys conducted by GANDOLFO \& ANTUNIASSI (2003) found that $60.4 \%$ had at least one nonfunctional anti-drip mechanism, and the average obtained was of 2.5 damaged anti-drip mechanisms per machine.

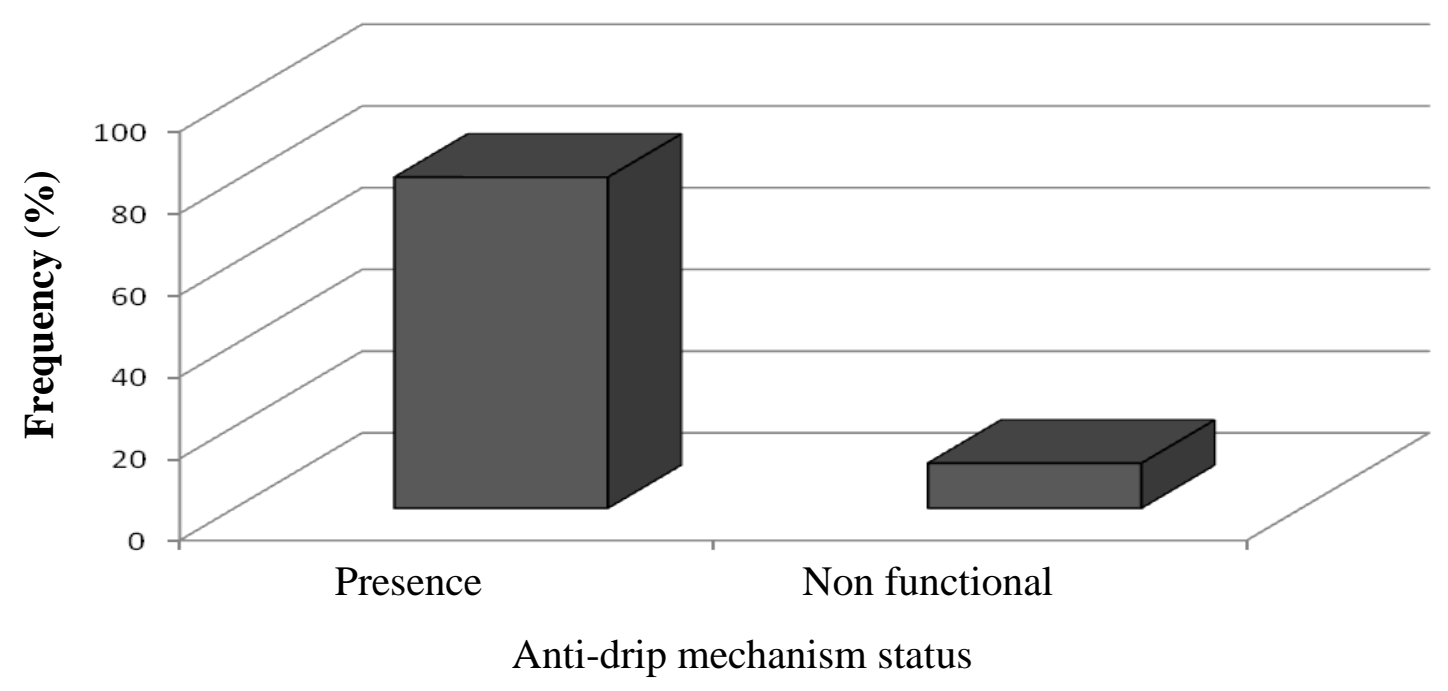

FIGURE 3. Evaluation of anti-drip mechanism use condition.

\section{Leakage presence}

Leaks were present in 26 units $(28.6 \%)$ and the places where they most frequently occurred were at the bars, where 20 units showed problems $(22.0 \%)$, the drive with 10 units $(11.0 \%)$ and mechanical stirrer with eight units (8.8\%). Leaks were observed in only $0.5 \%$ of sprayers in Belgium (LANGENAKENS, 1999; Huyghebaert et al. 1996). The authors found the same problem on $0.5 \%$ of equipment in use in Germany. 


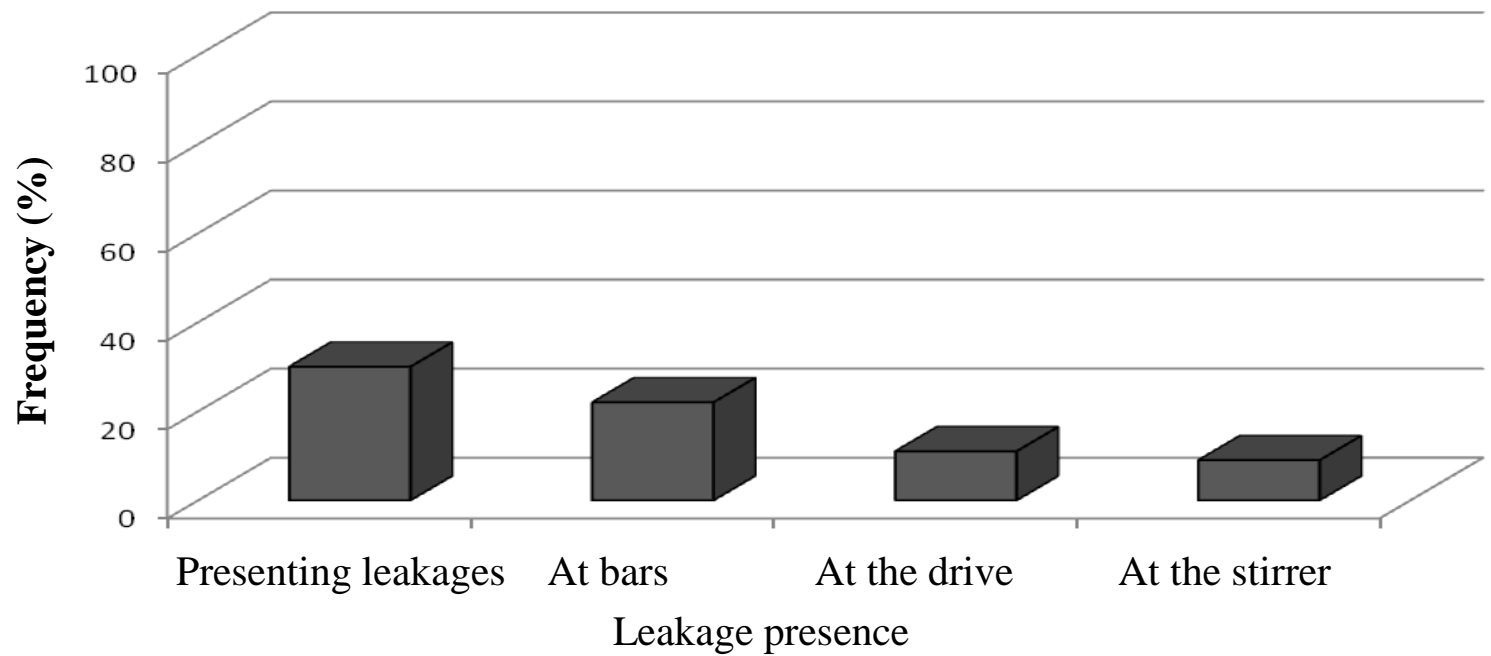

FIGURE 4. Evaluation of leakage presence.

\section{Presence and status of line filters}

Of the total sprays evaluated, only eight units $(8.8 \%)$ did not use line filter. Of the 83 machines that presented them, $16(17.6 \%)$ had some type of damage on the filter, and obstruction were present in 12 units (13.2\%). Adding machines without filters to the ones with damaged filters there is a total of 24 machines, which corresponded to $26.4 \%$ of equipment being used in improper conditions. GANDOLFO \& ANTUNIASSI (2003) observed that 59.2\% of the machines evaluated in their study also presented such conditions. In turn, SILVEIRA (2006) found that $25.0 \%$ of the evaluated machines in this situation. Although in Belgium, the occurrence of machines with this kind of failures was $3.7 \%$ (LANGENAKENS, 1999).

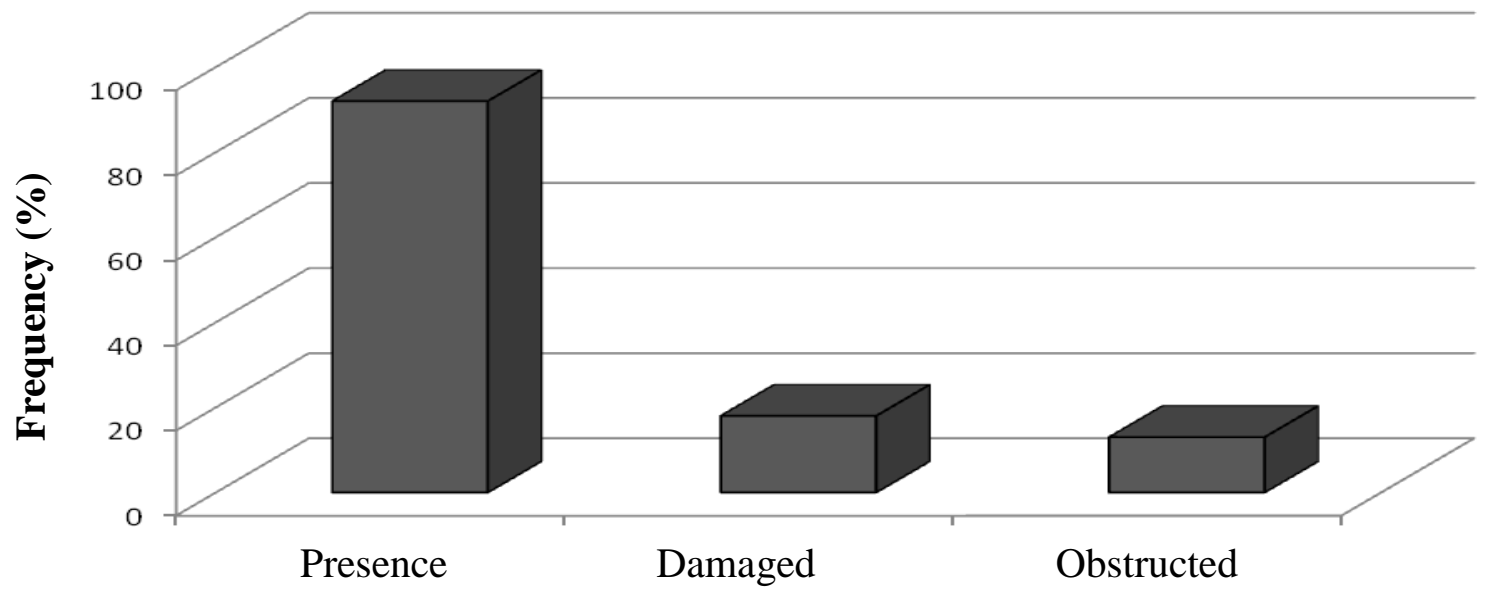

Presence and use condition of line filters

FIGURE 5. Evaluation of presence and use condition of line filters.

\section{Presence and status of suction filters}

Evaluations have shown that only one machine did not have the suction filter (1.1\%), and nine (9.9\%) of the 90 remaining machines had some type of problem. The main problem was filter obstruction, present in seven units (7.7\%). GANDOLFO \& ANTUNIASSI (2003) found problem in $11.8 \%$ of the machines evaluated. BALESTRINI (2006), when inspecting sprayers in Argentina, found $59.0 \%$ of malfunctioning filters. 


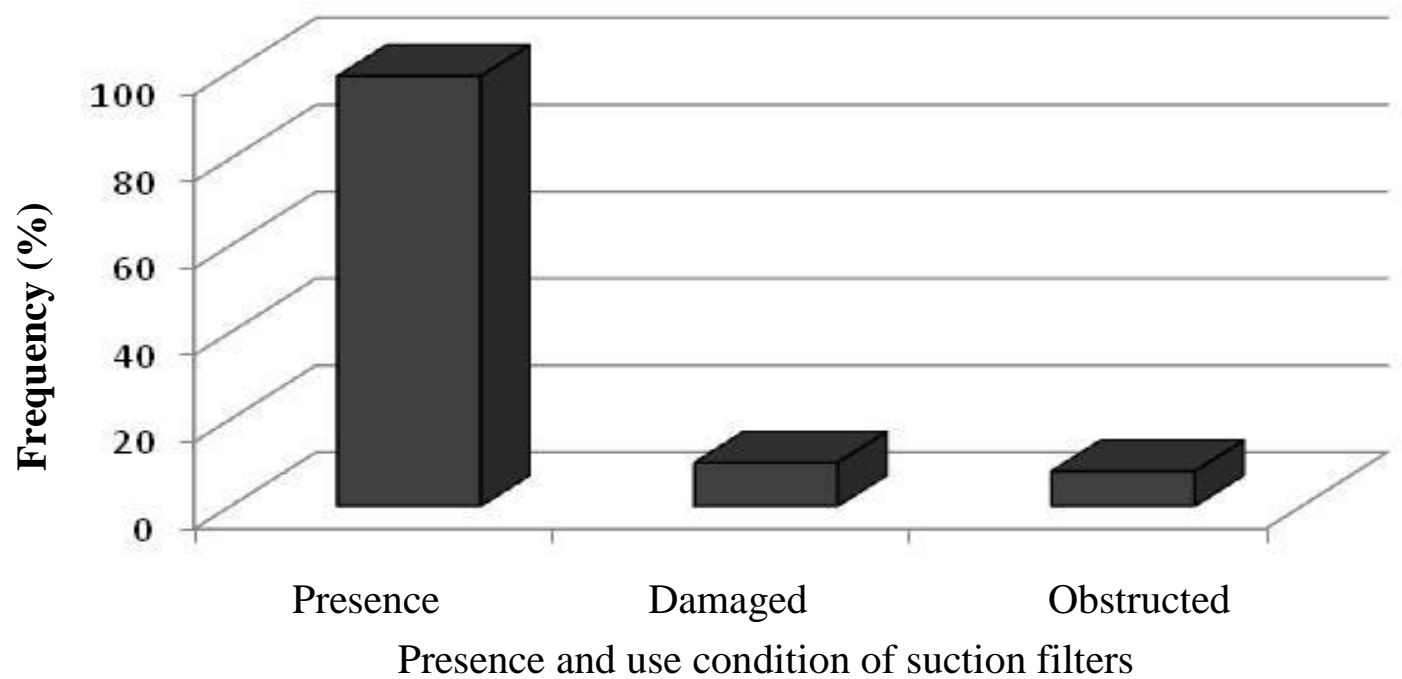

FIGURE 6. Evaluation of presence and status of suction filters use condition.

\section{Status of spraying nozzles}

It was found that 30 machines $(33.0 \%)$ had all their spraying nozzles in a state suitable for use, and the remaining ones $(67.0 \%)$ had at least one obstructed or worn nozzle. Inadequate nozzles due to obstruction were present in $47(51.6 \%)$ machines, where it was found an average of 3.5 obstructed nozzles per machine. Worn nozzles were present in 43 units $(47.3 \%)$ and the average was 3.7 worn nozzles per machine. Of the total number of sprayers, 32 units $(35.2 \%)$ had at least one obstructed and one worn nozzle. These results are similar to those found by GANDOLFO \& ANTUNIASSI (2003), who observed issues of inadequate nozzles in $81.6 \%$ of the evaluated units in the states of Paraná and São Paulo. From the evaluated sprayers in Belgium, only $1.4 \%$ presented problems (HUYGHEBAERT et al., 1996). RAMOS and CORTES (2006) evaluated sprayers in Spain, reporting that $94.0 \%$ also showed flow difference between them.

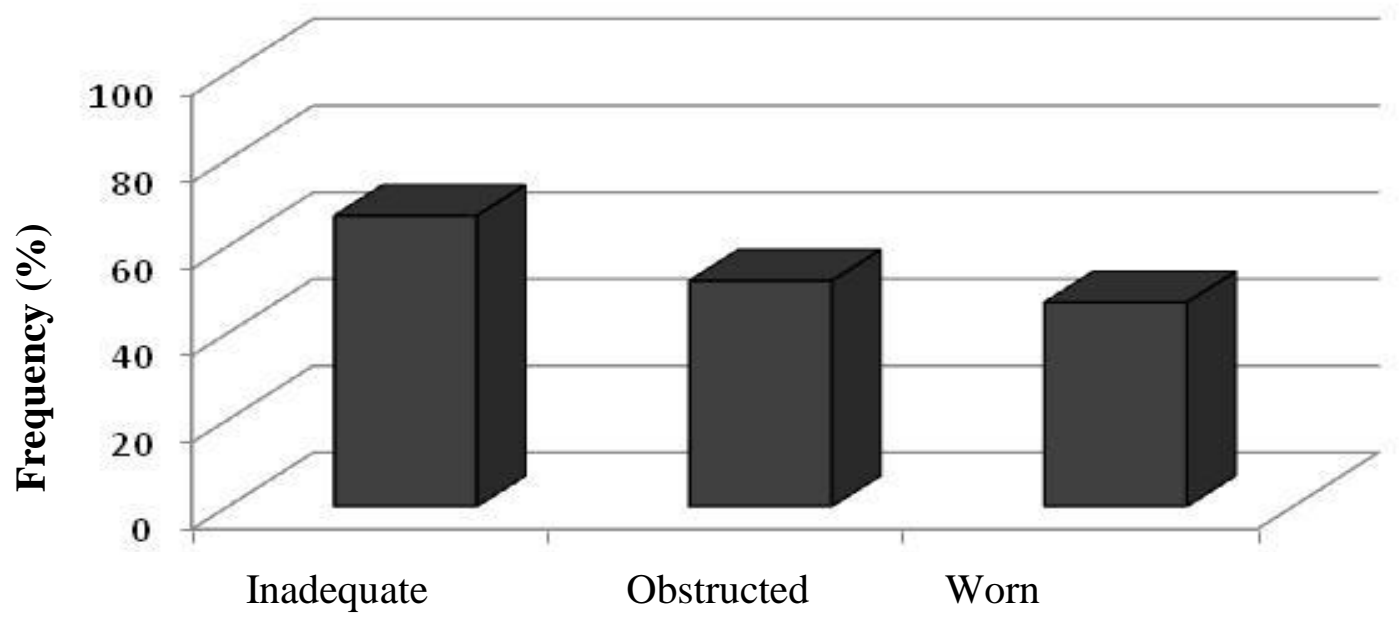

Sprayer nozzles use condition

FIGURE 7. Evaluation of sprayer nozzles use condition.

\section{Application rate}

The comparison between the calibration performed by the user and the used to measure showed that 63 units $(69.2 \%)$ applied spray volumes with a difference that exceeded the limits of $\pm 5.0 \%$ of the desired amount. Twenty-one $(23.1 \%)$ pieces of equipment whose user application rate exceeded the error limit characterized over-application (application with rate exceeding $5.0 \%$ of the 
desired), and the average error was $14.0 \%$ above the desired application rate. The biggest mistake in over-application was $26.9 \%$.

Regarding under-applications (sprayings whose application rate did not reach $95.0 \%$ of the application rate required), the occurrence took place in 42 machines (46.2\%), with an average error of $21.0 \%$ and higher error of $49.5 \%$ or less. GANDOLFO \& ANTUNIASSI (2003) and GANDOLFO et al. (2007) found errors in the application rate of $80.2 \%$ and $85.0 \%$, respectively. Regarding the amount of errors in the application rate, changes were observed in overdose of 14.0 to $22.0 \%$, and variations in sub-dose of 12.0 to $18.0 \%$. HUYGHEBAERT et al. (1996) considering the same error limit of $5 \%$ more or less got in Belgium errors in only four units of 2,952 inspections, which accounted for only $0.1 \%$ of the machines with errors on application rate.

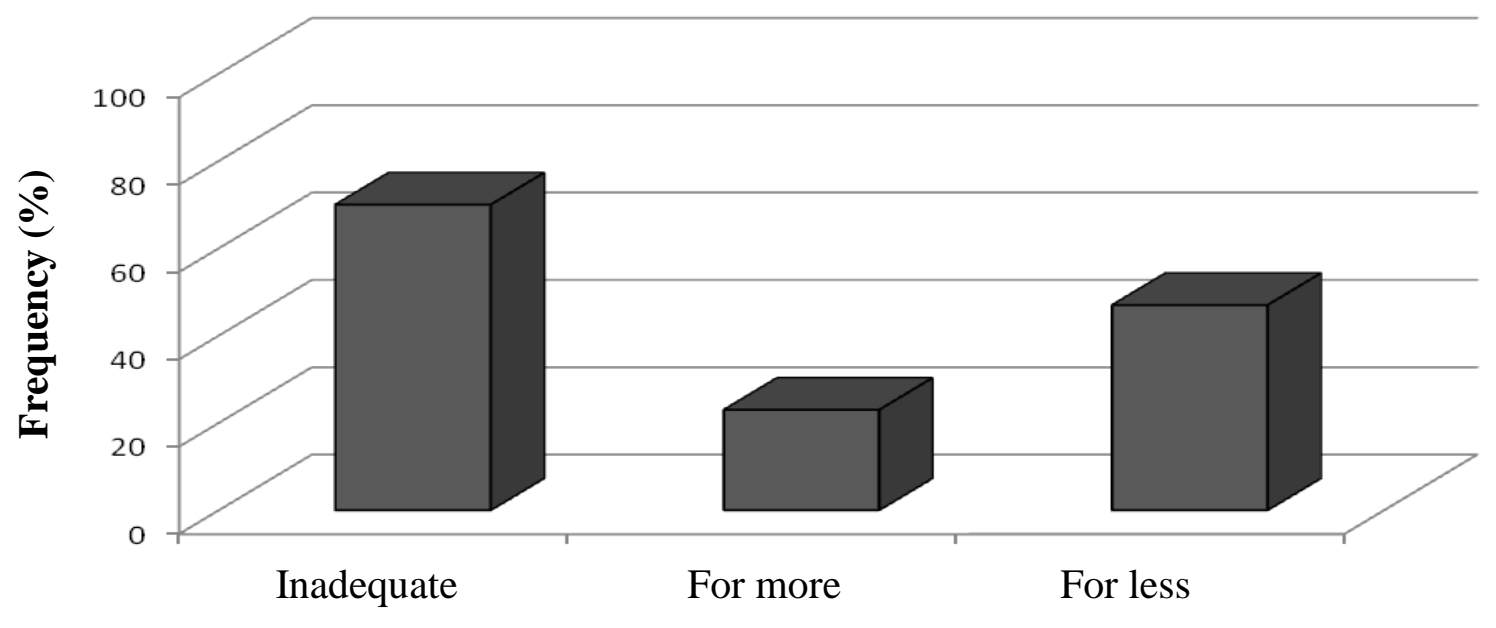

Errors between the application rate required and obtained

FIGURE 8. Evaluation of application rate errors.

\section{General evaluation}

When considering all variables measured in this study, it was found that 89 facilities had at least one operational problem (97.8\%), i.e., if the inspection was carried out by assigning, as is practiced in some countries, approval to machines without problems, only two units evaluated would be able to perform the work they were intended to do.

The simultaneous occurrence of inappropriate items with greater frequency in the machines was seven items, occurring in 22 pieces of equipment. It was further observed that equipment 67 (73.6) had five or more inadequate items, which may indicate a high level of concurrency problems in these devices (Figure 9).

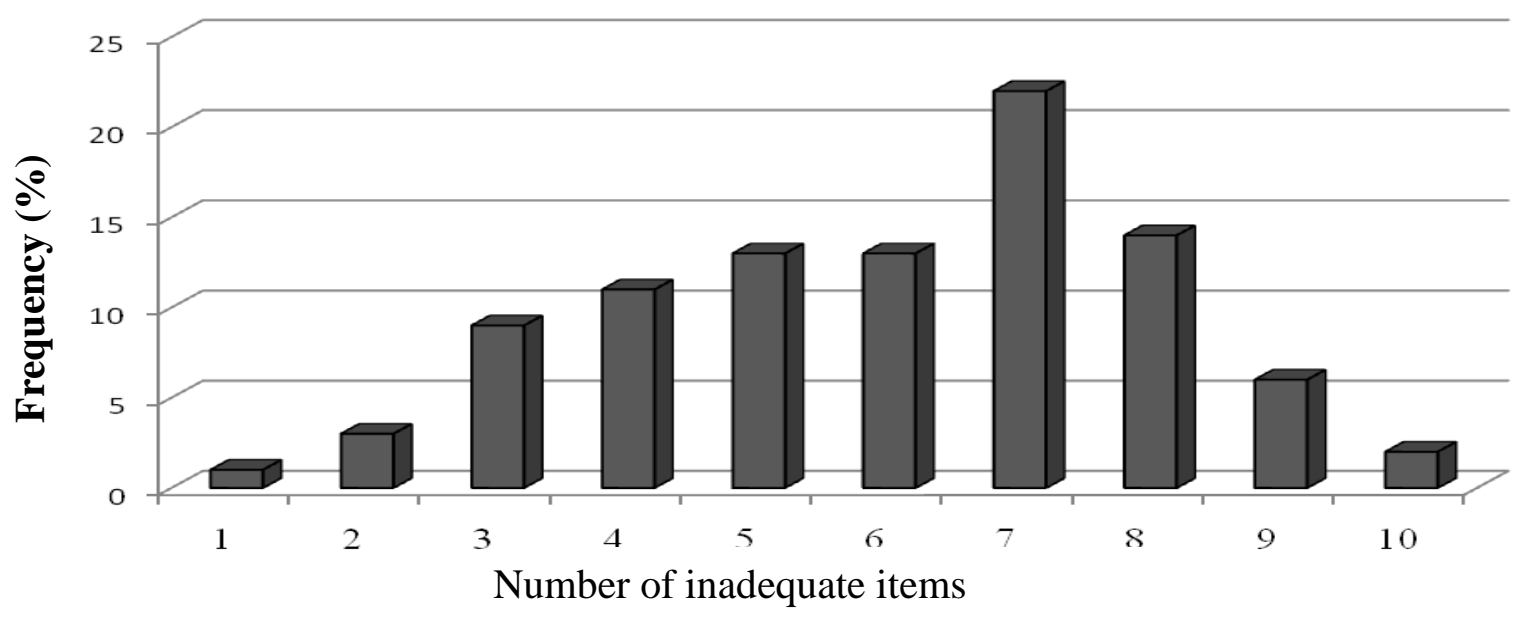

FIGURE 9. Occurrence of number of machines and correspondent number of inappropriate items. 
Table 2 shows the occurrence of problems according to the item evaluated in inspections. It is observed that problems related to the manometer, spraying nozzles and the application rate represent the most frequent errors.

TABLE 2. Occurrence of problems in function of evaluated item in the inspections.

\begin{tabular}{lc}
\hline Assessed item & error \% \\
\hline Missing, broken or inadequate manometer & 84.6 \\
Poor or poorly located hoses & 57.1 \\
Missing or nonfunctional anti-drip mechanisms & 22.0 \\
Presence of leakages & 28.6 \\
Missing or nonfunctional line filter & 26.4 \\
Missing or nonfunctional suction filter & 11.0 \\
Obstructed or worn spraying nozzles & 67.0 \\
Obstructed spraying nozzles & 56.1 \\
Worn spraying nozzles & 47.3 \\
Application rate errors & 69.2 \\
Application rate errors for more & 23.1 \\
Application rate errors for less & 46.1 \\
Some kind of irregularity & 97.8
\end{tabular}

\section{Final considerations}

The high prevalence of inadequate results observed in this study indicates the need for actions that provide better use condition of these machines to better quality in the application of pesticides in crops.

Excluding the problems related to manometer, which cannot even interfere with the inadequate quality of the application if the sprayers are well calibrated, problems related to the status of nozzles and errors in the application rate can mean, besides the high occurrence, also problems of greater impact on the quality of the application of agrochemicals. Thus, it is understood that better maintenance to homogenize the flow between nozzles could provide a more precise calibration and favor maximization of the application efficiency by improving the distribution of products in the treated area, minimizing costs at the lowest agrochemical loss and reducing environmental contamination by the lowest mistake of the applied dose.

It also must be considered that the differences in the dose of agrochemical distributed in the operating range of the equipment related both to differences in the flow of nozzles and to the calibration errors may predispose the crop to an increased risk of phytotoxicity at areas of overdose, when a phytotoxic product is used, such as requiring early reapplications in sub-dose locals in the reduction of residual products, in addition of limiting the efficiency of agrochemical agent against damage.

Besides the mentioned problems, there is also the loss of productive potential due to the competitiveness of the crop with the damage agents, which will be more intense the lower the efficiency of chemical sprays to control these agents.

\section{CONCLUSIONS}

Almost all of the evaluated machines showed maintenance and calibration problems, indicating the need for actions to improve the operating condition of this equipment.

The occurrence of problems in evaluated sprays in this study was higher than that observed in other countries, which could indicate a lower quality with which the agrochemicals are applied in that region of Brazil. 
The highest rates of problems found in sprayers were regarding the use of manometers in inadequate condition followed by errors in the application rate and irregular flow of spray nozzles. This indicates that the sprayings are performed with errors in the amount of agrochemical that is distributed in the treated area.

\section{REFERENCES}

ANTUNIASSI, U.R.; GANDOLFO, M.A. Periodic inspection on crop sprayers: results according to age of sprayers. Journal of Environmental Science and Health, New York, v.40, n.1, p.195-200, 2005.

BALESTRINI, L. Mobile inspection and diagnosis service of sprayers in resistance prevention. Results obtained out of inspections performed by a group of producers during the 20042005Season. Resistant Pest Management Newsletter, Michigan, v.16, n.1, p.5-7, 2006.

BAUER, F. C.; RAETANO, C. G.; PEREIRA, F. A. R. Padrões de distribuição volumétrica de pontas de pulverização de jato plano 11002, com e sem indução de ar, sob diferentes espaçamentos e alturas. Engenharia Agrícola, Jaboticabal, v.26, n.2, p.546-551, 2006.

CTIA. CÂMARA TEMÁTICA DE INSUMOS AGROPECUÁRIOS. Ministério do desenvolvimento, indústria e comércio exterior. Brasília, 2009.

CUNHA, J.P.A.R.; RUAS, R.A.A. Uniformidade de distribuição volumétrica de pontas de pulverização de jato plano duplo com indução de ar. Pesquisa Agropecuária Tropical, Goiânia, v.36, n.1, p.61-66, 2006.

GANDOLFO, M. A.; ANTUNIASSI, U. Inspeção periódica de pulverizadores agrícolas. Energia na Agricultura, Botucatu, v.18, n.2, p.67-76, 2003.

GANDOLFO, M.A.; ANTUNIASSI, U. R.; DALARMI, L. P.; CANATO, G.; BENTO, G.; DIAS, A. R. Avaliação de erros na taxa de aplicação na vazão das pontas em pulverizadores agrícolas. In: SIMPÓSIO DE ENGENHARIA RURAL, 1., 2007, Bandeirantes. Anais... Bandeirantes:

Universidade Estadual do Norte do Paraná, 2007.

GANZELMEIER, H.; WEHMANN, H.J. Second European Workshop on Standardized Procedure for the inspection of sprayers in Europe. Nachrichtenblatt des Deutschen Pflanzenschutzdienstes, Berlin, v.59, n.10, p.233-236, 2007.

HUYGHEBAERT, B.; MOSTADE, O.; CARRE, J.; DEBOUCHE, C. Compulsory inspection of crop sprayers already in use in Belgium: Selection of control method. AgEng Madrid 96, Madrid, v.26, p.79-86, 1996.

LANGENAKENS, J. Spraying nozzles: usability limits. St. Joseph: ASAE, 1999.

RAMOS, F.J.G.; CORTÉS, M.V. Inspección técnica de equipos para la aplicación de fitosanitarios. Vida Rural, Zaragoza, v.227, p.38-42, 2006.

SANTOS, S. R. dos.; MACIEL, A. J. da S. Proposta metodológica utilizando ferramentas de qualidade na avaliação do processo de pulverização. Engenharia Agrícola, Jaboticabal, v.26, n.2, p.627-636, maio/ago. 2006.

SILVEIRA, J.C.M.; FILHO, A.G.; PEREIRA, J.O.; SILVA, S. de L.; MODOLO, A.J. Avaliação qualitativa de pulverizadores da região de Cascavel, Estado do Paraná. Acta Scientiarum.

Agronomy, Maringá, v.28, n.4, p.569-573, oct./dec. 